International Journal of Physical Sciences and Engineering
Available online at http://sciencescholar.us/journal/index.php/ijpse
Vol. 2 No. 2, August 2018, pages: $32 \sim 38$
e-ISSN : 2550-6943, p-ISSN : 2550-6951
http://dx.doi.org/10.29332/ijpse.v2n2.141

\title{
Attitudes toward the Use of Internet for Students
}

\section{Wayan Suryasa a, I Gede Putu Adhitya Prayoga ${ }^{\mathrm{b}}$, I Wayan Astu Werdistira ${ }^{\mathrm{c}}$}

Article history: Received 9 February 2018, Accepted in revised form 1 June 2018, Approved 20 June 2018, Available online 7 July 2018

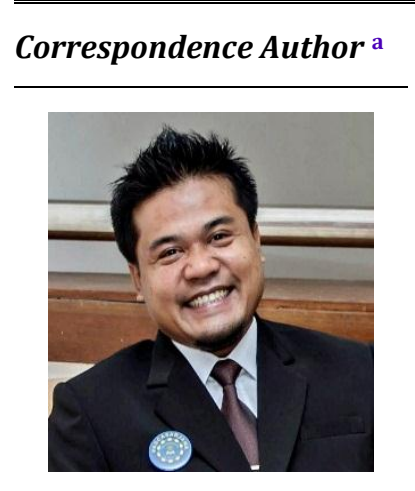

\section{Keywords}

Attitudes;

Information;

Internet;

Negative attitude;

Positive attitude;

\begin{abstract}
In this era, the internet has become the main media utilized by many people. In Indonesia, teenagers use the internet to find some information related to school, work, and lifestyle. The Internet makes a range of distance and time is no longer an obstacle in obtaining information. It can be accessed in every place and every time. However, if the teenagers do not use the internet wisely or they use it to find some negative contents on websites, it will result in negative impacts on them. This study aimed at investigating some attitudes toward the use of the internet for students. The samples of the study were students in SMA $\mathrm{N} 1$ Kediri. The method used was a survey by asking the students to fill out a questionnaire. The findings show that most of the students give a positive attitude toward the use of the internet for students. Most of them argue that crimes will be decreased if the students used the internet wisely. Also, there will be many creative ideas initiated by students for the development of this country.
\end{abstract}

e-ISSN: 2550-6943, p-ISSN: 2550-6951 ๑Copyright 2018. The Author. SS Journals Published by Universidad Técnica de Manabí. This is an open-access article under the CC BY-SA 4.0 license (https://creativecommons.org/licenses/by-sa/4.0/) All rights reserved.

\section{Contents}

Abstract 32

1. Introduction

2. Research Method 33

3. Results and Analysis

4. Conclusion Conflict of interest statement and funding sources... Statement of authorship Acknowledgements References 


\section{Introduction}

Interconnection network (internet) is a global system of all interconnected computer networks. The Internet comes from the Latin "inter" which means "between". The Internet is a network of billions of computers around the world. The Internet involves different types of computers as well as different network topologies. In managing the integration and network communication, the Internet protocol standard is used TCP / IP. TCP is responsible for ensuring that all relationships work well, while IPs are assigned to transmit data packets from one computer to another. In general, the Internet can be said as a network technology that allows people to communicate with each other without being spread by distance problems.

Currently, internet users in Indonesia have reached 71.19 million users (Badan Pusat Statistik, APJII, 2015). This is not surprising because every day the number of internet users in Indonesia is always increasing. Internet users in Indonesia take advantage of this technology for various things, such as sending electronic mail (e-mail), social media, or just looking for information.

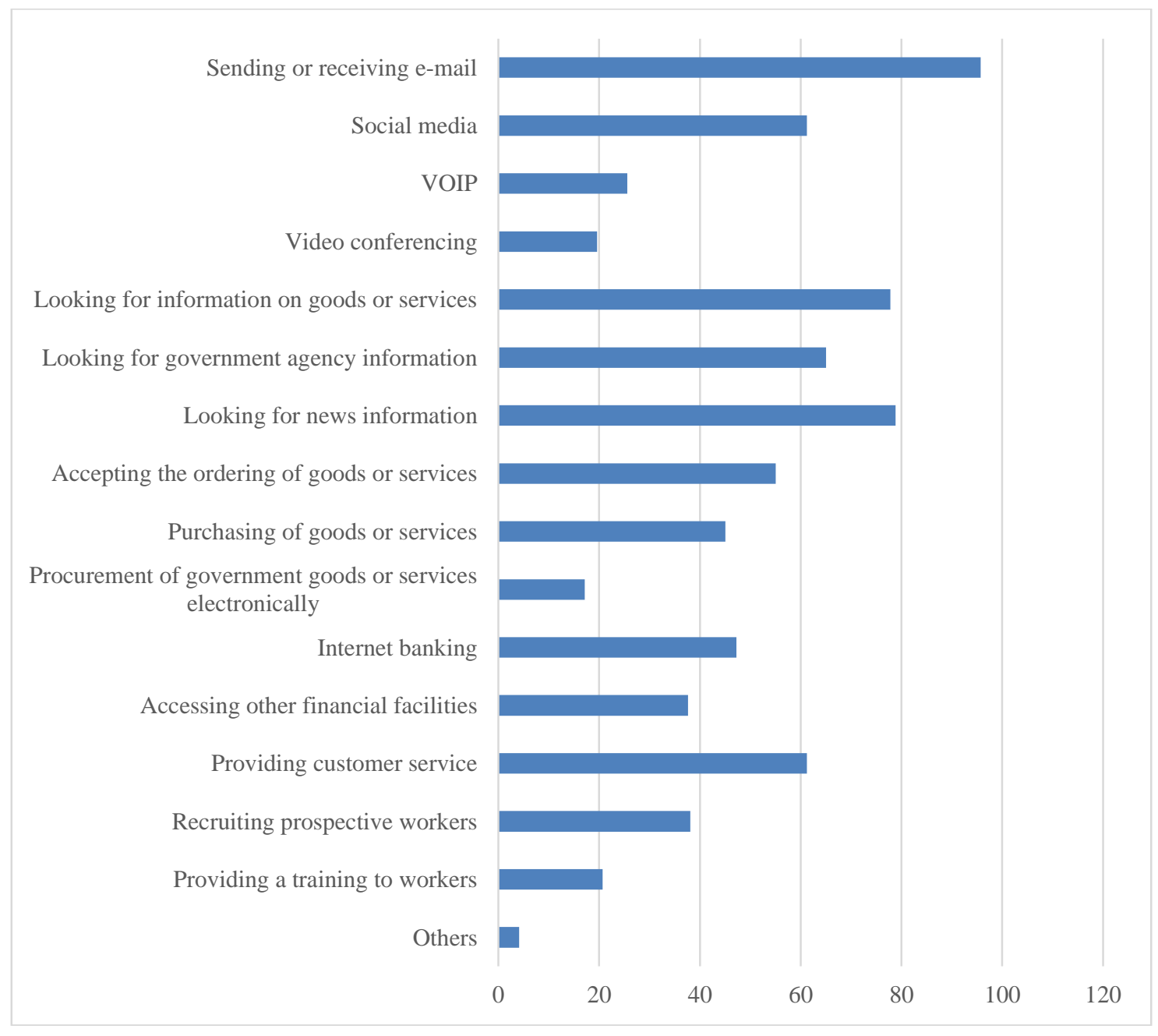

Graph 1. Distribution of Indonesian internet usage

Suryasa, I., Prayoga, I., \& Werdistira, I. (2018). Attitudes toward the use of internet for students. International Journal Of Physical Sciences And Engineering (IJPSE), 2(2), 32-38. doi:10.29332/ijpse.v2n2.141 
Teenagers in Indonesia are fairly active internet users. They take advantage of the Internet for various things ranging from just looking for information, to make friends, even not infrequently the teenagers also use the internet to do business. So many of the benefits felt by teenagers about the use of the internet make more and more teenagers active using internet technology.

But behind all the benefits of internet technology, there are also negative impacts that will be generated by this technology. As a network technology that is global and universal, then any information and from anywhere easily we get through the internet. Therefore, as users, we not only find positive information on the internet, but also information that is full of negative content such as pornography, gambling, violence, and other negatives. Moreover for teenagers, then this will be very dangerous if the content - content that is seen and obtained by teenagers in Indonesia is negative content. This will very quickly impact on their behavior, where adolescence is a period where a person is growing up and very easy to be affected by negative things.

SMA Negeri 1 Kediri Tabanan is one of the high schools in Tabanan district that has more than 1000 students, of course, also have utilized internet technology. Even now the students are also very easy in accessing information on the internet through their respective phones. Of course, this is quite worrying for the teachers and parents of students because it could be the students are accessing content - content that is negative.

Students' attitude toward the use of the internet is important to discuss. Attitudes are cognitive and effective; that is, they are related to thought as well as to feelings and emotions (Brown; 2000). Attitudes begin developing early and are influenced by many things, including parents, peer, and interactions with people who have social and cultural differences. According to Gardner (1985) attitudes are a component of motivation, which "refers to the combination of effort plus desire to achieve the goal of learning plus favorable attitudes towards learning the language."

Brown (2000) proposes two types of attitude, such as positive and negative attitudes. An individual who has a positive attitude will pay attention to the good things, rather than the bad ones. However, people with a negative attitude ignore the good and pay attention to the bad things. Positive attitudes are rewarded. It means the individual is encouraged to do the same thing in future. In contrast, negative attitudes are punished in order to discourage the same action in the future.

Based on the explanation above, this study focused on investigating the students' attitude toward the use of internet in SMA N 1 Kediri. Whether they have a high level of positive attitude or even negative attitude.

\section{Research Method}

30 students at SMA N 1 Kediri were selected as samples. They were chosen randomly. Thus, the samples were from grade 10,11 , and 12 . Of the total group of participants, $60 \%$ was female and $40 \%$ was male. This study is a kind of survey. It is conducted by delivering a questionnaire to each sample. The questionnaire contains 10 statements. There are 5 statements which belong to the positive attitude. Here are they:

a) I often use the internet for finding information about school lessons.

b) I think the internet helps me to explore knowledge.

c) I think the internet helps me to solve my problems.

d) The Internet has a big impact on my education career.

e) I often read online books.

These 5 statements belong to the negative attitude:

a) I often use the internet for using social media.

b) I always spend a lot of time watching online videos

c) I mostly use the internet to play online games.

d) I use the internet to find answers for my test in the class.

e) I think the internet helps me to be more fashionable.

A Likert scale was used in the questionnaire. It is a psychometric scale commonly involved in research (Wuensch, 2005). The students have to respond to each state whether they strongly disagree, disagree, neutral, agree, and strongly agree. The students may choose 'neutral'. There is no right and wrong answer.

The data obtained from the questionnaires were analyzed using the SPSS program. The data were calculated and presented in percentage. A five-point scale was used to measure the level of attitude. Such scale 
was used in the questionnaire to specify the level of the agreement or disagreement based on the following criteria:

Table 1

Mean Range for attitude level

\begin{tabular}{cc}
\hline Mean Range & Interpretation \\
\hline $3.68-5.00$ & High degree of attitude \\
$2.34-3.67$ & Moderate degree of attitude \\
$1.00-2.33$ & Low degree of attitude \\
\hline
\end{tabular}

\section{Results and Analysis}

In this section, presents details of the study's results. The following two table (Table 2 and 3) outlines all the 10 statements, their resulting itemized mean scores, using descriptive statistics of Mean Scores and Standard Deviation (S.D.) and their corresponding attitude levels, which serve the basis for further interpretation and implications. The following Table 2 contains 5 positive attitude related items.

Table 2

Positive attitude

\begin{tabular}{clccc}
\hline No & \multicolumn{1}{c}{ Statements } & Mean & S.D & Rating of Attitude Level \\
\hline 1 & $\begin{array}{l}\text { I often use the internet for finding information } \\
\text { about school lessons. }\end{array}$ & 4.57 & 0.92 & High \\
2 & $\begin{array}{l}\text { I think the internet helps me to explore } \\
\text { knowledge. }\end{array}$ & 4.10 & 0.60 & High \\
3 & & & High \\
& $\begin{array}{l}\text { I think the internet helps me to solve my problems. } \\
\text { The Internet has a big impact on my education }\end{array}$ & 4.30 & 0.75 & High \\
$\quad \begin{array}{l}\text { career. } \\
\text { I often read online books. }\end{array}$ & 4.43 & 0.50 & High \\
$\quad$ Total & 4.38 & 0.71 & \\
\hline
\end{tabular}

Table 2 reveals that the respondents possessed a high-level attitude. This is clearly seen by the average mean score of 4.38 on the table. Statement number 1 has the highest mean (4.57). The statement number 4 has an average mean score of 4.53 . The statement number 5 has an average mean score of 4.43 . And the statement number 3 has an average mean score of 4.30. The lowest mean score of 4.10 is statement number 2 . However, the overall mean score of positive attitude demonstrates a high level of attitude.

Table 3

Negative attitude

\begin{tabular}{clccc}
\hline No & \multicolumn{1}{c}{ Statements } & Mean & S.D & Rating of Attitude Level \\
\hline 6 & I often use the internet for using social media. & 4.37 & 0.71 & High \\
7 & I always spend a lot of time watching online videos & 3.57 & 0.50 & Moderate \\
8 & I mostly use the internet to play online games. & 3.40 & 0.53 & Moderate \\
9 & I use the internet to find answers for my test in the & 3.30 & 0.45 & Moderate \\
& & & High \\
class. & & & \\
I think the internet helps me to be more fashionable. & 4.17 & 0.56 & \\
& Total & 3.76 & 0.55 & \\
\hline
\end{tabular}

Suryasa, I., Prayoga, I., \& Werdistira, I. (2018). Attitudes toward the use of internet for students. International Journal Of Physical Sciences And Engineering (IJPSE), 2(2), 32-38. doi:10.29332/ijpse.v2n2.141 
Table 3 reveals that the respondents possessed a moderate level of negative attitude. This is clearly seen by the average mean score of 3.76 on the table. Statement number $6,10,7$, and 8 show the highest level with the mean scores of 4.37, 4.17, 3.57, and 3.40. The statement number 9 has the lowest mean score which is 3.30 and is considered as a moderate level of attitude.

Table 4

The Comparison between Positive Attitude and Negative Attitude

\begin{tabular}{cccc}
\hline Attitude & Mean & S.D. & Meaning \\
\hline Positive & 4.38 & 0.71 & High \\
Negative & 3.76 & 0.55 & Moderate \\
Total & 4.07 & 0.63 & High \\
\hline
\end{tabular}

Table 4 presents the comparison between positive and negative attitude. It reveals that the mean score of positive attitude (4.38) is higher than the mean score of a negative attitude (3.76). However, the overall mean scores of both types of the attitude of 4.07 are considered as a high degree of attitude.

The overall results reveal that the students have a high degree of a positive attitude toward the use of the Internet. This finding answers the research question of what the level of the subjects' attitude is. Based on the comparison and assessment, it is discovered that the students are having a more positive attitude toward the use of the Internet. This finding has relevant implications and should be recommended for further training or studies.

\section{Conclusion}

In conclusion, this study was gathered to provide some insights into the level and type of attitude of the students at SMA N 1 Kediri. Using the survey method, the questionnaires, and then were analyzed by using SPSS program. The findings show that the students are having a more positive attitude toward the use of the Internet

\section{Conflict of interest statement and funding sources}

The author) declared that they have no competing interest. The study was financed by IW Suryasa.

\section{Statement of authorship}

The authors have a responsibility for the conception and design of the study. The authors have approved the final article.

\section{Acknowledgments}

The authors would like to give huge thanks to the people who involved in this study for the advice so this study could be completed well. 
References

1. Bento, A. C. (2018). Internet of Things: An Experiment with Residential Automation for Robotics Classes. International Research Journal of Management, IT and Social Sciences (IRJMIS), 5(2), 113-119. View in (Google Scholar)

2. Billaiya, R., Malaiya, S., \& Parihar, K. S. (2017). Impact of Socio Economic Trends on Students in Quality Education System. International Journal of Social Sciences and Humanities (IJSSH), 1(1), 16-20. View in (Google Scholar)

3. Brown, H. D. (2000). Principles of language learning and teaching. View in (Google Scholar)

4. Gardner, R. C. (1985). Social psychology and second language learning: The role of attitudes and motivation. Arnold.

View in (Google Scholar)

5. Jain, P. (2017). Effect of Online Education Trend on Quality Management. International Journal of Health Sciences (IJHS), 1(1), 1-5.

View in (Google Scholar)

6. Wuensch, K. L. (2005). What is a likert scale? and how do you pronounce'likert?'. East Carolina University, 4.

View in (Google Scholar)

Suryasa, I., Prayoga, I., \& Werdistira, I. (2018). Attitudes toward the use of internet for students. International Journal Of Physical Sciences And Engineering (IJPSE), 2(2), 32-38. doi:10.29332/ijpse.v2n2.141 


\section{Biography of Authors}

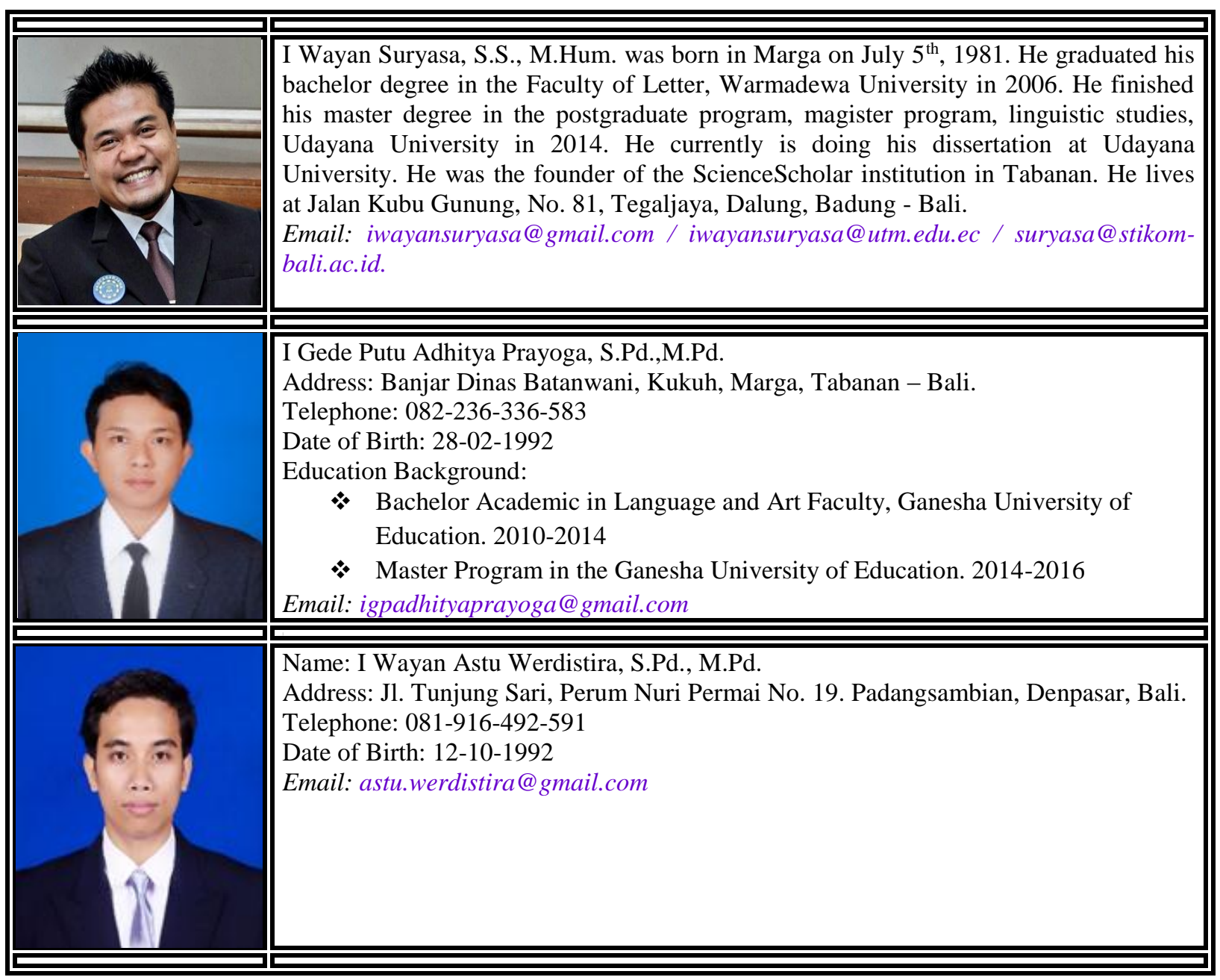

